\title{
SERUM ELECTROLYTES AND BLOOD PRESSURE OF APPARENTLY HEALTHY NIGERIANS
}

C. E. UGWU

(Received 26, November 2008; Revision Accepted 28, January 2009)

\begin{abstract}
The serum electrolytes and blood pressures of apparently healthy Nigerians were studied. A total of 121 subjects took part in the study. The serum electrolytes $\left(\mathrm{Na}^{+}, \mathrm{K}^{+}, \mathrm{CL}^{-}, \mathrm{HCO}_{3}^{-}\right)$and blood pressure were measured by standard methods. The mean $( \pm S D)$ serum sodium, potassium, chloride and bicarbonate concentrations were $142.15 \pm 15.16$, $5.17 \pm 1.04,98.50 \pm 11.22$ and $26.55 \pm 8.17 \mathrm{mEq} / \mathrm{L}$ respectively while the mean $( \pm S D)$ systolic and diastolic blood pressure were $117.67 \pm 11.75$ and $73.21 \pm 9.64 \mathrm{~mm} / \mathrm{Hg}$ respectively. The mean blood pressure and serum concentrations of the electrolytes generally fall within the reference range though some were outside the normal range.

The mean serum level of potassium was found to be higher than results obtained from other regions of the country while the mean sodium and chloride ions concentrations were lower than the results obtained from Zaria, northern Nigeria. It is likely that both geographical locations and dietary habits among Nigerians might influence these differences. The study suggests that in interpreting results of electrolytes and blood pressure for clinical uses, both geographic (climatic) conditions and dietary factors should be considered.
\end{abstract}

\section{KEYWORDS: Serum Electrolytes, Blood pressure, Nigerians.}

\section{INTRODUCTION}

The importance of water in fluid and electrolyte balance is well documented. Along with chloride, potassium, and water, sodium is important in establishing osmotic pressure relationship between intracellular and extra cellular fluids.

Animal studies (as well as limited epidemiological and clinical observations) suggest that diets high in sodium chloride may also have deleterious cardiovascular consequences independent of blood pressure (MacGregor, 1997). In humans, evidence for an association between electrolytes consumption and blood pressure is based on anthropological research, observational epidemiological studies (cross-population and within population) and intervention trails (ICRG, 1988).

A review of a limited number of observational and intervention studies suggest that there is an association between sodium chloride consumption and blood pressure level in children and adolescents (Simons- Morton and Obarzanek, 1997).

Environmental factors, including differences in other dietary mineral contents and socioeconomics status, may also contribute to the apparently greater prevalence of salt sensitivity among African Americans (Grim et al, 1984). Geographical locations have been shown to account for differences observed in serum potassium levels in normal men from different ethnic groups (Reidenerg et al, 1993). The high incidence of systemic hypertension in black population has been associated with high intake as well as high sodium potassium ratio in this population (Morris and Sebastian, 1995). It is likely that both geographical locations and different dietary habits among Nigerians might influence the blood pressure and the concentration of electrolytes in individuals.

An understanding of these associations has important implications not only for the prevention and treatment of hypertension but also for developing population - based strategies to decrease cardiovascular disease risk by shifting the overall blood pressure distribution towards lower levels. The relationship between dietary electrolyte consumption and blood pressure in apparently healthy Nigerians is the main focus of the study.

\section{MATERIALS AND METHODS}

The participants used in this work were residents of the university town of Nsukka, south eastern, Nigeria. The study was conducted from January to April of 2006. This comprised 54 males and 67 females. Blood samples were collected from 121 apparently healthy subjects. All samples in the study were collected and analyzed within 2 hours. To encourage consent and alley the anxiety of the volunteers, the aim of the study was explained. They were grouped into five age ranges of 16-25, 26-35, 36$45,46-55$ and $\geq 56$ years respectively.

The blood pressure was measured with standard mercury sphygmomanometer, with appropriate CUFF size with the subject seated for at least five minutes, and using left arm. The diastolic pressure was taken at phase $\mathrm{V}$ (Korotkof sounds) and measurements were taken to the nearest $2 \mathrm{mmHg}$.

Serum sodium was estimated by the method of Maruna, (1958) with commercially prepared kit from Alpha Diagnostic Inc, Monterey park, CA, USA. Serum Chloride was estimated by the method of Cotlove(1964), 
with kits obtained from TECO Diagnostic, Anaheim, CA, USA. Serum bicarbonate was enzymatically estimated (Forrester et al, 1976) using reagents kits supplied by TECO Diagnostic, Anaheim, CA, USA.

\section{STATISTICS}

Statistical analysis was undertaken using SPSS version 10.0. Data collected were subjected to analysis of variance (ANOVA) using factorial in completely randomized design (CRD). The mean $\pm S D$ of each parameter was taken for each group. Significance test of mean was by fishers least significant difference (F-LSD). The acceptable level of significance was $P<0.05$.

\section{RESULTS}

Table 1: Mean serum electrolytes concentration $(\mathrm{mEq} / \mathrm{L})$ and mean blood pressure $(\mathrm{mm} / \mathrm{HG})$ of the total subjects, males and females

\begin{tabular}{|c|c|c|c|c|c|c|}
\hline & $\begin{array}{c}\text { Sodium } \\
\mathrm{Na}^{+} \\
(\mathrm{mEq} / \mathrm{L})\end{array}$ & $\begin{array}{l}\text { Potassium } \\
\mathrm{K}^{+}(\mathrm{mEq} / \mathrm{L})\end{array}$ & $\begin{array}{l}\text { Chloride, } \\
\mathrm{Cl}^{-}(\mathrm{mEq} / \mathrm{L})\end{array}$ & $\begin{array}{l}\text { Bicarbonate } \\
\mathrm{HCO}_{3}^{-} \\
\text {(mEq/L) }\end{array}$ & $\begin{array}{l}\text { SBP } \\
(\mathrm{mm} / \mathrm{Hg})\end{array}$ & DPB (mm/Hg) \\
\hline $\begin{array}{l}\text { Total } \\
\mathrm{N}=121\end{array}$ & $142.15 \pm 15.16$ & $5.17 \pm 1.04$ & $98.50 \pm 11.22$ & $26.55 \pm 8.17$ & $117.67 \pm 11.75$ & $73.21 \pm 9.64$ \\
\hline Males $N=54$ & $142.35 \pm 17.76^{a}$ & $4.74 \pm 1.47^{\mathrm{a}}$ & $90.94 \pm 9.75^{a}$ & $26.90 \pm 9.09^{a}$ & $117.61 \pm 12.31^{a}$ & $72.96 \pm 9.71^{a}$ \\
\hline Females $\mathrm{N}=67$ & $141.99 \pm 18.12^{\mathrm{a}}$ & $5.51 \pm 9.42^{\mathrm{a}}$ & $75.60 \pm 13.31^{\mathrm{a}}$ & $21.81 \pm 7.41^{a}$ & $117.71 \pm 11.36^{\mathrm{a}}$ & $73.41 \pm 9.66^{\mathrm{a}}$ \\
\hline
\end{tabular}

Results are mean \pm SD

Values with different superscripts in a row are significantly different $(P<0.05)$

SBP: Systolic Blood Pressure.

DBP: Diastolic Blood Pressure.

Table 2: Mean systolic and diastolic blood pressure of the different age groups.

\begin{tabular}{|l|l|l|l|l|l|}
\hline $\begin{array}{l}\text { AGE } \\
\text { (years) }\end{array}$ & $\mathbf{1 6 - 2 5} \mathbf{n = 3 4}$ & $\begin{array}{l}\mathbf{2 6 - 3 5} \\
\mathbf{n}=\mathbf{3 3}\end{array}$ & $\begin{array}{l}\mathbf{3 6 - 4 5} \\
\mathbf{n}=\mathbf{2 6}\end{array}$ & $\begin{array}{l}\mathbf{4 6 - 5 5} \\
\mathbf{n}=\mathbf{1 0}\end{array}$ & $\begin{array}{l}\mathbf{5 6} \\
\mathbf{n}=\mathbf{1 8}\end{array}$ \\
\hline $\begin{array}{l}\text { SBP } \\
(\mathrm{mm} / \mathrm{Hg})\end{array}$ & $111.9 \pm 9.85^{\mathrm{a}}$ & $114.15 \pm 9.47^{\mathrm{a}}$ & $121.40 \pm 8.85^{\mathrm{a}, \mathrm{c}}$ & $130.60 \pm 11.70^{\mathrm{a}, \mathrm{c}}$ & $122.61 \pm 13.81^{\mathrm{a}, \mathrm{c}}$ \\
\hline $\begin{array}{l}\mathrm{DBP} \\
(\mathrm{mm} / \mathrm{Hg})\end{array}$ & $69.21 \pm 9.41^{\mathrm{b}}$ & $71.03 \pm 9.10^{\mathrm{b}}$ & $75.16 \pm 8.09^{\mathrm{b}}$ & $81.60 \pm 11.79^{\mathrm{b}}$ & $77.39 \pm 7.14^{\mathrm{b}}$ \\
\hline
\end{tabular}

Values with different superscripts in a row are significantly different $(P<0.05)$

Table 3: Some serum electrolyte concentration of the different age groups

\begin{tabular}{|l|l|l|l|l|l|}
\hline AGE (years) & $\begin{array}{l}\mathbf{1 6 - 2 5} \\
\mathbf{n = 3 4}\end{array}$ & $\begin{array}{l}\mathbf{2 6 - 3 5} \\
\mathbf{n = 3 3}\end{array}$ & $\begin{array}{l}\mathbf{3 6 - 4 5} \\
\mathbf{n = 2 6}\end{array}$ & $\begin{array}{l}\mathbf{4 6 - 5 5} \\
\mathbf{n = 1 0}\end{array}$ & $\begin{array}{l}\mathbf{5 6} \\
\mathbf{n = 1 8}\end{array}$ \\
\hline $\begin{array}{l}\text { Chloride ions } \\
\text { (mEq/L) }\end{array}$ & $\begin{array}{l}90.83 \pm \\
7.54^{\mathrm{a}^{\prime} \mathrm{b}}\end{array}$ & $\begin{array}{l}97.98 \pm \\
9.28^{\mathrm{a}^{\prime} \mathrm{b}}\end{array}$ & $\begin{array}{l}98.36 \pm \\
5.20^{\mathrm{a}}\end{array}$ & $\begin{array}{l}78.31 \pm \\
5.16 \mathrm{~b}\end{array}$ & $\begin{array}{l}92.06 \pm \\
10.17^{\mathrm{a}^{\mathrm{b}}}\end{array}$ \\
\hline $\begin{array}{l}\text { Bicarbonate ions } \\
\text { (mEq/L) }\end{array}$ & $25.59 \pm$ & $27.16 \pm$ & $26.78 \pm$ & $26.78 \pm$ & $29.01 \pm$ \\
\hline Sodium ions (mEq/L) & $7.51^{\mathrm{a}}$ & $7.76^{\mathrm{a}}$ & $9.17^{\mathrm{a}}$ & $9.32^{\mathrm{a}}$ & $8.50^{\mathrm{a}}$ \\
& $138.06 \pm$ & $145.65 \pm$ & $144.01 \pm$ & $139.35 \pm$ & $142.48 \pm$ \\
& $25.37^{\mathrm{a}}$ & $12.46^{\mathrm{a}}$ & $9.85^{\mathrm{a}}$ & $14.25^{\mathrm{a}}$ & $17.50^{\mathrm{a}}$ \\
\hline Potassium ion & $4.27 \pm$ & $6.73 \pm$ & $5.04 \pm$ & $5.19 \pm$ & $4.16 \pm$ \\
(mEq/L) & $1.26^{\mathrm{a}}$ & $13.24^{\mathrm{a}}$ & $1,84^{\mathrm{a}}$ & $0.82^{\mathrm{a}}$ & $1.11^{\mathrm{a}}$ \\
\hline
\end{tabular}

Results are mean \pm SD

Values with different superscripts in a row are significantly different $(P<0.05)$ 
Table 4: Mean concentration of serum electrolytes from different zones of Nigeria and results from the present study

\begin{tabular}{|l|l|l|l|l|}
\hline Parameters & Present study & Zaria & Ibadan & Kano \\
\hline chloride (mEq/L) & $98.50 \pm 11.22$ & $106.0 \pm 6.0$ & $92.0 \pm 7.8$ & $103.3 \pm 3.6$ \\
\hline Bicarbonate ions (mEq/L) & $26.85 \pm 8.17$ & $26.0 \pm 4.7$ & $21.0 \pm 3.7$ & $25.9 \pm 19$ \\
\hline Sodium ions (mEq/L) & $142.15 \pm 15.16$ & $145.0 \pm 3.5$ & $130.0 \pm 5.2$ & $138.3 \pm 2.9$ \\
\hline Potassium (mEq/L) & $5.17 \pm 1.04$ & $4.8 \pm 0.6$ & $3.5 \pm 0.8$ & $4.4 \pm 0.39$ \\
\hline
\end{tabular}

Results are mean \pm SD

\section{DISCUSSION}

Table 1 shows mean serum electrolyte concentrations and mean blood pressures of the total subjects, male and females. There were no significant difference $(p>0.05)$ in the mean systolic blood pressure (SBP), diastolic blood pressure (DBP), serum chloride, bicarbonate, sodium and potassium ions respectively in the sampled population.

The results in Table 2 shows the mean systolic and diastolic blood pressure of all the age groups. The mean SBP increased with age with the age group $46-$ 55 years recording the highest mean value of $130.60 \pm 11.70 \mathrm{~mm} / \mathrm{Hg}$ which was significantly higher $(p<0.05)$ to the mean of all other age groups. The mean SBP of the age group $\geq 56$ years was significantly higher $(p<0.05)$ than that of age group $26-35$ and $16-25$ years. There were no significant differences $(p>0.05)$ in the mean diastolic pressure of the different age groups.

The reference rage for the SBP and DBP were reported to be $\leq 140 / 90 \mathrm{~mm} / \mathrm{Hg}$ (Adedoyin and Adeniyi, 2001). The mean SBP and DBP observed in the study falls within this range. About 65.29 percent of the mean SBP were within the reference range whereas only 26.45 percent was on the high side of the reference range. Of the 22 subjects with high SBP values 6 subjects each were of the age groups of $36-45$ and 4655 years respectively while 5 subjects belonged to the age group $\geq 56$ years.

The reference range for the serum chloride concentration has been reported to be $96-110 \mathrm{mEq} / \mathrm{L}$ (Dandekar and Rane, 2004). The mean values (Table 1) and the mean from the different age groups (Table 3 ) largely falls within the normal reference value of $96-110$ $\mathrm{mEq} / \mathrm{L}$. Of the 121 samples analysed 76 subjects $(62.8 \%)$ had a serum chloride concentration below $96 \mathrm{mEq} / \mathrm{L}$ while 22 subject $(18.2 \%)$ had serum values greater than $120 \mathrm{mEq} / \mathrm{L}$, considered the upper limit of normal. The mean serum level were lower (Table 4) than the mean values reported in Zaria (Isichiei, 1978) and in Kano (Sule et al, 2001) but higher than the value reported at Ibadan (McFarlane et al, 1970).

The study shows only 20 subjects $(16.5 \%)$ had abnormal high serum sodium ion level with 37 subjects $(30.6 \%)$ being within the reference rage of $143-155$ $\mathrm{mEq} / \mathrm{L}$ (Dandekar and Rane, 2004) while 64 subjects had a serum level of $143 \mathrm{mEq} / \mathrm{L}$. The increase in this case is not up to the level which could cause hypernatremia and its associated consequence in the studied population. Wotton and Freeman, (1982) have reported a direct relationship between serum sodium and chloride ions. The mean serum sodium level in the subjects studied (Table 4) were higher than the mean values reported in Ibadan (South west) and Kano (North central), Nigeria but lower than the mean value reported at Zaria (north central), Nigeria. It has been previously reported by Sule et al (2001)of a direct relationship between serum sodium ion, that is an increase in serum chloride ion occurs when there is and increase in serum sodium and vice versa. It should be noted that serum chloride ion concentration in the body is related to sodium concentration as well as to the regulatory ability of aldosterone on the renal tubules of the body.

The reference range for the serum potassium concentration has been reported to be $3.3-5.3 \mathrm{mEq} / \mathrm{L}$ (Dandekar and Rane. 2004). Twenty two subjects had their potassium ion level below the lower limit of 3.3 $\mathrm{mEq} / \mathrm{L}$ whereas 35 subjects $(28.9 \%)$ where on the high side of the reference range. Of he 35 subjects with high values, 21 subjects belonged to the age groups of 36 $45,46-55$ and $\leq 56$ years respectively. Forty percent of these subjects were females.

The mean serum potassium level in the subjects studied were higher than the reports from Zaria (Ischei, 1978) and in Kano (Sule et al, 2001), northern Nigeria while the result from Ibadan (McFarlane et al, 1970) is the lowest (Table 4). The serum potassium ion concentration is not a good measure of the total body potassium because most of the potassium ion is sequestered within the cells. Fortunately, the clinical manifestation of potassium ion deficiency correlated well with the serum concentration. Increasing potassium intake lowers blood pressure in both hypertensive and normotensive people (He and MacGregor, 2001). Forty one subjects $(33.9 \%)$, recorded serum bicarbonate ion values above $28 \mathrm{mEq} / \mathrm{L}$ considered the lower limit of normal. Of these 41 subjects the age groups 16-25 and 26-35 years had 13 and 10 subjects respectively. Seventy one percent of these subjects with relatively high serum bicarbonate values were females. However, 21 subjects $(17.46 \%)$ had a serum bicarbonate concentration below $24 \mathrm{mEq} / \mathrm{L}$ considered the lower limit of the normal. This decrease could be associated with increased presence of excess hydrogen ions imposed by the liberation of acid in the body. This is corrected by increased conversion of bicarbonate ions to carbonic acid which dehydrates to carbon dioxide and $\mathrm{H}_{2} \mathrm{O}$. The mean serum bicarbonate Value is similar to the mean reported at Zaria and Kano but higher than that of Ibadan Southwest Nigeria (Table 4).

The study suggests an elevated mean blood pressure and mean serum electrolytes concentration when compared to the results from other regions with Ibadan having the lowest values. It is clear that the results obtained in the studies could have significant clinical implication in the interpretation of results from 
different regions of the country. It can also be deduced from table 4 that while Kano and Zaria (northern Nigeria) recorded relatively high values, the results from Ibadan and the present study should have also recorded similar trend. The basis for the differing serum values between the northern and southern Nigeria is not completely clear. The observed difference could be attributed to differences in dietary, climatic and socio-cultural conditions. It is important to note that there is differences in the pattern of dietary salt intake in different sociocultural zones of Nigeria.

The higher serum values observed in the present study may be related to decreased total body water as the study was conducted during dry season. The high temperature and low humidity (January to April) observed at South-eastern Nigeria goes with lower urinary and sweat output leading to very low loss of electrolytes.

The results from the study showed progressive increase in the systolic blood pressure values with the sodium and chloride ion concentration as the age group increased (Table 2 and 3). The effect of high sodium intake in the risk of cardiovascular disease has long been debated. Much of this effect is thought to be mediated through raised blood pressure (ICRG, 1989), although experimental data indicate that other mechanisms might also be involved (Gracia et al, 1997).

Four factors are considered established risk factors for high blood pressure: high sodium intake; low potassium intake; obesity and excessive alcohol drinking (Elliot, 2003). The rise in blood pressure with age leading to the development of unfavorable blood pressure patterns in populations, along with smoking and unfavorable blood lipid profiles (related to diet), are the key factors underlying this world wide epidemic (Elliot, 2003). Body mass index and sodium ion could act independently on blood pressure (Dyer et al, 1994) and a high sodium intake could have some direct effects on cardiovascular risk not mediated by blood pressure.

The possibility of a cause - and - effect relationship between the observed serum values of the electrolytes and blood pressure values in the studied population should be further investigated to reduce the risk to renal and cardiovascular diseases.

\section{CONLUSION}

This results show that the serum electrolytes and blood pressure of the studied population were on the average within the normal range though some were outside the normal range. The results also show that climatic factors influence the electrolytes concentration and blood pressure values of the subjects. This study, therefore, suggests that in interpreting results of electrolytes and blood pressure for clinical uses, both geographic (climatic) conditions and dietary factors should be considered.

\section{REFERENCES}

Adedoyin, O. T. and Adeniyi, A., 2001. Prevention of hypertension in children in the tropics. Africa Health $17 ; 16-18$
Cotlove, E., 1964. Determination of chloride in biological materials. In: methods of Biochemical Analysis. Vol 12 Glick, D (ed) New York, Interscience Publishers Inc.

Dandekar, P. S. and Rane, S. A. 2004. Practical and viva in medical biochemistry. Elsevier, New Delhi, India. Pp 156.

Dyer, A. R., Elliot, P., Shipley, M. and Starnler, J., 1994. Relation of body mass index to associations of sodium and potassium with blood pressure: The INTERSALT study. Hypertension. 23: 729-736.

Elliot, P., 2003. Protein intake and blood pressure in cardiovascular disease. Proceeding of nutrition 62: 495-504.

Forrester, R. L, Wataji, L. J, Silverman, D. A. and Pierre, K. J., 1976. Enzymatic method for the determination of $\mathrm{CO}_{2}$ in serum. Clin. Chem. 22:243.

Gracia, G., Cattanco, B. M., Serville, G., Lanfanchi, A., Bolla, G. and Monica, G., 1997. Baroreflex impairment by low sodium diet in mild or moderate essential hypertension. Hypertension 29: 802-807.

Grim, C. E., Luft, F. C., Weinberger, M.H., Miller, J. Z., Rose, R. J. and Christian, J. C., 1984. Genetic, familial, and racial influences on blood pressure control systems in man. Aust. N Z J. Med. 14: 453-457.

He, F.J. and MacGregor, G.A.(2001). Clinical review. Beneficial effects of potassium BMJ. 323: 497501.

Intersalt Cooperative Research Groups (ICRG), 1988. INTERSALT: an international study of electrolyte excretion and blood pressure. Results for $24 \mathrm{hr}$ urinary sodium and potassium excretion. Br. Med. J. 297: 319-328.

Intersalt Cooperative Research Groups (ICRG) 1989. The intersalt study. J. Hum. Hypertens. 3: 279331.

Isichei, U. P., 1978. Relative hyperelectrolytemia in northern Nigerians. Int. J. Trop. Med. Hyg. 27(5):1049-1051.

MacGregor, G. A., 1997. Salt -More adverse effects. AM.J. Hypertens. 10:375-415.

Maruna, R. F. L., 1958. Clin. Chem. Acta. 2: 581.

McFarlane, H., Akinkugbe, O. O., Adejuwon, A. C. Oforfuo, I.A.O. and Reddy, S., 1970. Biochemical normal in Nigerians with particular reference to electrolyte and urea Clin. Chem. 
Morris, R. C. and Sebastian, A., 1995. Potassium responsive hypertension. In: hypertension pathophysiology, Diagnosis, and management. Second edition. Laragh, J. H. and Brener, B.M. (eds). Raven Press, New York, 2715-2726.

Reidenberg, M.M., Gu, Z.P., Lonenze, B., Cotinho, E., Athayde, C., Frick, J., Alvarez, F., Brcaho, V. and Emuveyan, F., 1993. Differences in serum potassium concentrates in normal man in different geographical locations. Clin. Chem. 39(1): 7275.

Simons-Morton, D. G. and Obarzanek, E., 1997. Diet and blood pressure in children and adolescents.
Pediatr nephrol. 11: 244 - 249.

Sule, M. S., Usman, Z. L. and Alhassan, A. J., 2001. Serum electrolyte levels of pregnant women in Kano, Nigeria. J. of Biochemistry and Molecular biology. 16(3): 32-34.

Tietz, N. W., Pruden, E. L. and Siggard-Anderson, O., 1986. Electrolytes, Blood gases and Acid base balance. In Textbook of Clinical Chemistry. Tietz, N.w. (ed). W.B. Suander, Philadelphia. 1177-1188.

Wotton, I. D. P. and Freeman, H., 1982. Electrolytes: In microanalysis in Medical Biochemistry. $6^{\text {th }}$ edition. New York. Pp 51 - 52. 